Dmytro BONDARENKO,

Doctoral student, University of Szeged, Hungary,

e-mail:dbond70@gmail.com,

ORCID ID: https://orcid.org/0000-0003-1608-1282,

ResearcherID: X-9811-2019,

https://publons.com/researcher/3108443/dmytro-bondarenko/

\title{
THE REVOLUTION-COUNTER-REVOLUTION PROCESS IN CENTRAL AND EASTERN EUROPE, 1917-1920: THE THEORETICAL OVERVIEW
}

The topic of this article is to conceptualize briefly the processes of revolution and counter-revolution in some states of Central and Eastern Europe in 19171920 basing on the most significant historical and sociological research of Pitirim Sorokin, Oskar Jaszi, Charles Tilly, Piotr Sztompka, etc., revealed the main phases and the trends of these processes. It is shown that in spite of the processes of revolution and counter-revolution in the different countries of Central and Eastern Europe had the same causes, the phases and trends of development, but led to different and even opposite results. The peak of the revolution in all the considered states was Bolshevism and the Red Terror, and it was precisely the counter-revolution that emerged as a response to Bolshevism. Thus, the counter-revolution emerged on the second phases of the revolutionary process and also had some stages. As history showed, the revolutionary process had the similar causes and the phases, but led to different results. For instance, if, in Finland and Hungary, Bolshevism was defeated and the counter-revolution won, then, in Russia, on the contrary, the Bolsheviks managed to retain the power. This problem is explored in this article, applying the comparative historical analysis.

Key words: Revolution; Counter-revolution; the Monarchist Counterrevolution; Restoration; Central and Eastern Europe in 1918-1920; Bolshevism; Pitirim Sorokin; Charles Tilly; Oskar Jaszi.

Two events of World History marked the beginning of new epochs: the Great French Revolution, according to Eric Hobsbawm and Ivan Berend, opened the "Long XIX century" (1789-1914) ${ }^{1}$, the era of nationalism, liberalism, and capitalism, and the Great Russian Revolution of 1917 ushered in the era of socialism and totalitarianism. As for the Marxist historians, there is no doubt that 1917 became the starting point of Contemporary History, and it was the Socialist Revolution in Russia that changed the World. However, not only the Marxists believe that the Bolshevik Revolution in Russia was the phenomenon that disintegrated the old world, led to the global crisis of international

\footnotetext{
${ }^{1}$ Hobsbawm E. The Age of Revolution: Europe, 1789-1848. London : Weidenfeld \& Nicolson Ltd., 1962.366 p.; Idem The Age of Capital, 1848-1875. London : Weidenfeld \& Nicolson Ltd., 1975. 384 p.; Idem The Age of Empire, 18751914. London : Weidenfeld \& Nicolson Ltd., 1987. 404 p.; Berend I. History Derailed: Central and Eastern Europe in the Long Nineteenth Century. Oakland : University of California Press, 2003. 404 p.
} 
relations system and created the problems which are the actual in the world today ${ }^{2}$. Both revolutions went far beyond the borders of the states of their origin in their historical significance and politicalgeographical scales, and claimed universality.

In this context, the question arises about the origin of the revolution as a historical phenomenon, its patterns, trends, and main phases.

Fist attempts to explain the origin and the trends of the revolution were made in Russia by Pitirim Sorokin ${ }^{3}$ and in Hungary by Oskar Jaszi ${ }^{4}$. Moreover, among huge number theories of the revolutionary process (many of them are reviewed by Barbara Salert ${ }^{5}$, Jack Goldstone ${ }^{6}$, and Cecil Lindholm ${ }^{7}$ ), the above mentioned are still the most substantiated by Central and Eastern European illustrations (the former Russian and the Austro-Hungarian Empires).

The purpose of this article is to think afresh about the revolution-counter-revolution process in Central and Eastern Europe, or more precisely, the former Russian and the Austro-Hungarian Empires (Russia, Finland, Ukraine, Don, Hungary), by the end and aftermath of the First World War (1917-1920).

The methodology this article has the following basis: Leopold von Ranke's historicism ${ }^{8}$, John Tosh's theory of historical research ${ }^{9}$, and Matthew Lange's and Miroslav Hroch's comparative historical methods ${ }^{10}$.

Studying the revolutionary process, it is very important to define the basic terms such as "revolution", "counter-revolution", "restoration", etc. The term "revolution" has many definitions, but generally, researchers define revolution as a violent change of the existing system ${ }^{11}$. For instance, most of the researchers accepted Arthur Bauer's definition: "Revolution is a change of constitutional and social order, committed by force" ${ }^{\text {"12 }}$. Consequently, Restoration is the process which opposes the revolution, i.e. the return to the old regime, as a rule, the monarchy ${ }^{13}$. According to Alfred Meusel's definition, Counter-revolution is "an attempt to reverse the transformations

\footnotetext{
${ }^{2}$ Palmowski J., Spohr Readman K. Speaking Truth to Power: Contemporary History in the Twenty-First Century //Journal of Contemporary History. 2011. Vol. 46, No 3. P. 485, 487-488, 490, 502-503; Spohr Readman K. Contemporary History in Europe: From Mastering National Past to the Future of Writing the World // Journal of Contemporary History. 2011. Vol. 46, No 3. P. 508, 514; Catterall P. What (if anything) is Distinctive about Contemporary History? //Journal of Contemporary History. 1997. Vol. 32, No 4. P. 451.

${ }^{3}$ Sorokin P. The Sociology of Revolution. Philadelphia : J. B. Lippincott Co., 1925. хіi, 428 р.; Сорокин П. Социология революции. Москва : РОССПЭН, 2005. 704 с.

${ }^{4}$ Jászi O. Revolution and Counter-Revolution in Hungary. London : P. S. King and Son, 1924. xxiii, 236 p.; Idem. Revolution and Counter-Revolution in Hungary. New York : Howard Fertig, 1969. 239 p.

${ }^{5}$ Salert B. Revolutions and Revolutionaries: Four Theories. Santa Barbara : Praeger Publishers, 1981. 161 p.

${ }^{6}$ Goldstone J. Theories of Revolution: The Third Generation // World Politics. 1980. Vol. 32, No. 3. P. 425-453; Revolutions: Theoretical, Comparative, and Historical Studies / Ed. by J. Goldstone. Belmont : Thomson Wadsworth, 2002. 352 p.

${ }^{7}$ Lindholm C. The First and the Fourth Generation of Revolutionary Theories: A Common Ground for a Clinical Theory // Department of Political Science Abo Akademi University Occasional Papers Series. 2013. No 31. P. 1-40.

${ }^{8}$ Ranke L. von Preface: Histories of the Latin and Germanic Nations from 1494-1514 // The Varieties of History from Voltaire to the Present / Ed. by F. Stern. London \& Basingstoke : MacMillan Ltd.,1970. P. 54-62.

${ }^{9}$ Tosh J. The Pursuit of History: Aims, Methods and New Directions in the Study of Modern History. London : Longman, 2002. 368 p.

${ }^{10}$ Lange M. The Comparative Historical Methods. London, New Deli, Washington, Los-Angeles, Singapore : SAGE Pub., 2013. 208 p.; Hroch M. Social Preconditions of National Revival in Europe. A Comparative Analysis of the Social Composition of Patriotic Groups among the Smaller European Nations. Cambridge, London, New York, New Rochelle, Melbourne, Sydney : Cambridge University Press, 1985. P. 18.

${ }^{11}$ Штомпка П. Социология социальных изменений. Москва, 1996. С. 367, 371-372; Johnson Ch. Revolutionary Change. London, 1968. P. 1; Gurr R. Why Men Rebel. Princeton, 1970. P. 4; Skockpol, Th. States and Social Revolution. Cambridge, 1979. P. 4.

${ }^{12}$ Johnson Ch. Revolutionary Change. Stanford : Stanford University Press, 1982. Р. 1; Сорокин П. Революция и социология. Бойня: революция 1917 года // Сорокин П. Человек. Цивилизация. Общество. Москва, 1992. С. 269; Tilly Ch. European Revolutions, 1492-1992. Oxford : Blackwell Publishers Ltd, 1996. P. 5, 7, 9, 10; Idem. From Mobilization to Revolution. New York : Random House, 1978. P. 192-193, 202; Huntington, S. Political Order in Changing Societies. New Haven : Yale University Press, 1968. P. 264.

${ }^{13}$ Смолин О. Политический процесс в современной России. Москва : ТК Велби \& Проспект, 2004. С. 29.
} 
effected in a revolution" ${ }^{\prime 14}$. However, in O. Smolin's opinion, Counter-revolution is the struggle of some social groups and classes against the revolution, but this struggle is not necessary for the restoration of the old regime. For example, the Russian counter-revolution had both monarchical and republican platforms. Thus, Restoration and Counter-revolution are not identical concepts ${ }^{15}$. So, the success of the counter-revolution is a specific signal of the opportunity for restoration to the temporarily displaced classes by the revolution.

As Charles Tilly noted, there is no any special theory of counter-revolution, but analysis of counter-revolution has relied on the general conceptions of revolution. We should agree with his opinion that theory of revolution which could not account for the appearance of such phenomenon as counter-revolution would be considered incomplete, and which does not provide any understanding of the presence of counter-revolutionary forces within a society during revolt must leave the researchers unsatisfied ${ }^{16}$. However, for all that, the special theory of counter-revolution was created by Arno Mayer latter ${ }^{17}$.

The revolution, especially, in our case, the Bolshevik revolution strived for expansion beyond the geographical boundaries of the nation to rebuild the World as a whole. In this regard, the Bolsheviks even invented the concept of the so-called export-revolution. The Bolsheviks' main goal was to destroy all nation-states and create the World Soviet Republic through the "export of revolution" or "triumphal march of Soviet power". Thus, Soviet Russia became the base for the World revolution.

Certainly, it would be used also the term "export-counter-revolution", as an opposite process to the export-revolution, but this term is synonymous with intervention. For example, the counterrevolution and restoration were carried out in Ukraine by the German and Austro-Hungarian forces in 1918, and Hungary by the Romanian troops in 1919.

Studying the process of revolution, Pitirim Sorokin concluded that the very revolution is not a normal, but a deviation, a crisis of social development, violence, and a "tornado". Firstly, revolution means a change in the behavior of people, in their psychology, ideology, beliefs, and values. Secondly, the revolution marks a change in the biological composition of the population, especially if it accompanied by civil war and terror. Thirdly, it is the deformation of the entire social structure of society, the level of social mobility is increasing, political management is simplified, leading to dictatorship under the slogans of freedom. The main factors of the revolution are the following: ${ }^{18}$

- reduction of living standards of the population;

- degradation of the elite;

- paralysis of law enforcement;

- powerful anti-government propaganda.

Barrington Moore demonstrated the almost similar attitudes concerning the prerequisites of the revolution: ${ }^{19}$

1. The elite loses control over the army, politics, and instruments of suppression;

2. The emergence of conflict within the dominant classes;

3. The distribution of new thoughts and explanations of justice and human deprivation;

4. The mobilization of revolutionary masses against the background of the increase of poverty and deprivation.

Peter Calvert defined follows stages of revolutionary transition: ${ }^{20}$

1. The political orientation of the state becomes too discredited in the eyes of the population;

2. The change of government at a certain point in time through armed force, or the real threat of the use of force, is a key event;

\footnotetext{
${ }^{14}$ Tilly Ch. The Analysis of A Counter-Revolution // History and Theory, 1963. Vol. 3, No. 1. P. 30.

${ }^{15}$ Смолин О. Указ. Соч. С. 31-32.

${ }^{16}$ Tilly Ch. The Analysis of A Counter-Revolution... P. 30.

${ }^{17}$ Mayer A. Dynamics of Counter-revolution in Europe, 1870-1956. An Analytic Framework. New York \& Evanston

\& San Francisco \& London : Harper Torchbooks, 1971. 173 p.

${ }^{18}$ Сорокин П. Революция и социология. Бойня: революция 1917 года... С. 281, 285-287, 291.

${ }^{19}$ Tilly Ch. From Mobilization to Revolution... P. 201.

${ }^{20}$ Calvert P. A Study of Revolution. Oxford : Clarendon Press,1970. P. 4.
} 
3. An intelligible program of changing the political or social institutions of a state, or both, is induced by the new political leadership after the transfer of power has taken place;

4. The new political myth, that emerged as a result of the revolutionary transition, gives the political leadership the short-term status of the legitimate government of a state.

Alexis de Tocqueville distinguished two stages of the revolution. The first is the destruction of the basis of the old order, and the second is the creation of a new order, based on some norms of the old order. The first stage is the abolition of laws, morality, language, freedom, individualism, a weakening of power, social equality, terror, the destruction of the aristocracy, social egoism. The second stage is the strengthening of power, the restoration of legality and morality of the past, the creation of a new order with a new elite, a bureaucratic and centralized state, rule of law and the absence of class restrictions. After the revolution society returns to the norm based on a new order $^{21}$.

Pitirim Sorokin emphasized the following three phases of the revolutionary process: ${ }^{22}$

- The first is usually short-term, "overture" or festival of "holy freedom", i.e. liberation from the tyranny of the old regime and the expectations of the promised reforms. The government is humanistic and acts not by the force of law, but moral exhortations. Its policy is indecisive and powerless, for example, the Provisional Government, led by Prince George Lvov in Russia and the government of Count Mihály Károlyi in Hungary.

- The second is destructive, "tornado", reaction, dictatorship, the "worst of animals" begins to wake up. The great revolution turns into a horrific squall, indiscriminately sweeping away everything in its path. It ruthlessly eradicates not only the dilapidated, but also still viable institutions and values of society, and thereby eliminates not only the outdated political elite of the old regime but also many creative individuals and groups. The revolutionary government at this stage is ruthless, tyrannical, and sometimes bloodthirsty, and its policy is predominantly destructive, violent, and terrorist. (The Bolshevik rule in Russia, Ukraine, Finland, Hungary.)

- The third is constructive, "return to normal state". "Having destroyed all the counterrevolutionary forces, the revolution begins to create a new social and cultural order. Moreover, this new system is based not only on new revolutionary ideas but also revives the most resilient prerevolutionary institutions, values and methods of activity temporarily destroyed in the second phase of the revolution but reviving and reaffirming themselves against the will of the revolutionary government". Robert Merton defined this situation as a retreat, a return to old values, and healthy conservatism overcame in society, including as a result of the passive rejection of revolutionary ideals. Only after the reaction society returns to normal life, it means the end of the revolution.

In general, almost all researchers distinguish the following stages of the revolutionary process:

1. Euphoria (celebration of freedom) or revolutionary romanticism;

2. Destruction (permissiveness), decomposition, catastrophe;

3. The destruction of the opposition (counter-revolutionaries), revolutionary terror;

4. The return to the normal state or the reverse of "revolutionary pendulum".

In summarizing the above-mentioned Piotr Sztompka presented a more detailed scheme for the development of the revolution: ${ }^{23}$

1. The inability of the old authorities to govern. "Paralysis of the state" (for example, Russia and Austro-Hungary on the eve of disintegration);

2. The destruction of the old order. The euphoria of freedom;

3. The dominance of moderates, which are in contradiction with the expectations of the masses. The disappointment of the masses (for example, the Provisional Government in Russia and Mihaly Karolyi's government in Hungary);

4. Mobilization of the masses by radicals (in our case, the Bolsheviks);

5. Terror by radicals (in our case, the Red terror);

\footnotetext{
${ }^{21}$ Токвиль А. де Старый порядок и революция. Москва, 1997. С. 5-6.

${ }^{22}$ Сорокин П. Революция и социология. Бойня: революция 1917 года... С. 268-270.

${ }^{23}$ Штомпка П. Социология социальных изменений... С. 374.
} 
6. Restoring order, "Thermidor", "cure of revolutionary fever" (in our case it could be various variants: the victory of counter-revolution in Finland, restoration through the German and the Austro-Hungarian intervention in Ukraine and the Romanian intervention in Hungary, the NEP in Russia, etc).

It should be noted that Counter-revolution emerges during stage 2 of Alexis de Tocqueville's and Pitirim Sorokin's schemes or stage 5 of Piotr Sztompka's scheme, i.e. as a response to revolutionary terror to restore the order and rule of law and stop arbitrariness and outrage. The society achieves the stage 3 according to Pitirim Sorokin's scheme or stage 6 according to Piotr Sztompka's scheme (it means the transition to the normal) either by the victory of counter-revolution and restoration or the natural end of the revolution.

The counter-revolution emerges as a response to the revolutionary terror, in particular, the Bolshevik social experiment and the Red Terror.

According to Pavel Milyukov's conception, the counter-revolution proceeds two periods: the preparation and the struggle ${ }^{24}$, i.e., the latent and active phases. The counter-revolution has also three stages: the emergence, the struggle and, according to its result, the end with either the restoration or the defeat. Naturally, the counter-revolution emerges on state outskirts, as a counterbalance of the revolutionary capital of the state. For instance, after the Bolshevik coups in the capital cities (Petrograd in Russia, Helsinki in Finland, Budapest in Hungary), the Headquarters of national White governments were located on states outskirts, such as Vaasa in Finland; Szeged in Hungary; Samara, Ufa and then Omsk in Russia, etc. Some newly independent states emerged on the territory of the former Russian Empire, such as the Kingdom of Finland, the Ukrainian State, the Almighty Don Host, Estonian Republic, etc., became the bases of the Russian monarchist counterrevolution $^{25}$. Moreover, the Bolsheviks made historic analogies between Kiev and Koblenz, Don and Vendée, and Baron Karl Gustav Mannerheim, the Regent of Finland, was mentioned in the Bolshevik propaganda as a "head of the Russian White government" 26 . The counter-revolution won in Finland, Ukraine, Don in 1918, and Hungary in 1919, but, at the same time, was finally defeated in the European part of Russia in 1920. Sergey Melgunov defined the cause of the defeat of the Russian Whites in the geographical situation: the Bolsheviks occupied the central industrial region, but the White forces, on the contrary, less industrial and more agrarian ones ${ }^{27}$. However, under similar circumstances, Finland and Hungary had demonstrated the opposite results. Consequently, the geographical location was not the resulting factor. Certainly, the German intervention in Finland in 1918 and the Romanian one in Hungary in 1919 had a significant role in the victory over the Reds, but, whereas, in Russia, the German intervention in 1918 and the Entente intervention in 1918-1920 were insufficient and ineffective. Moreover, the defeat of Germany in the First World War led to the failure of the Russian monarchist counter-revolution ${ }^{28}$.

The restoration also took place with certain features of the country. For instance, in Finland, parliament introduced the Swedish Constitution of 1772 on 9 August 1918. Ukrainian and Don provisional Constitutions ("Laws on the Provisional State System of Ukraine" on 29 April 1918 and "The Basic Laws of Almighty Don Host" on 17 May 1918) almost repeated the norm of prerevolutionary Russian law. If in Finland and Hungary the monarchy, as a form of government in the state, was restored (respectively on 9 August 1918 and on 7 August 1919), then in Ukraine and Don preserved the republican form of government, but these states became the bases for the restoration of the monarchy in Russia.

\footnotetext{
${ }^{24}$ Милюков П. Россия на переломе: большевистский период Русской революции. Т. 2. ... С. 4; Мельгунов С. Гражданская война в освещении П. Н. Милюкова (По поводу “Россия на переломе"). Критикобиблиографический очерк. Париж, 1929. С. 15.

${ }^{25}$ Пайпс Р. Россия при большевиках. Москва : РОССПЭН, 1997. С. 44; Kenez P. Civil War in Souh Russia, 1918. The First Year of the Volunteer Army. Berkeley, \& Los Angeles : University of California Press, 1971. P. 135, 140, 144-147, 219-220, 238-240, 272; Федюшин О. Украинская революция 1917-1918. Москва : Центрполиграф, 2007. С. 177-177, 185, 187.

${ }^{26}$ Маннергейм К. Г. Мемуары. Москва : Вагниус, 1999. С. 141.

${ }^{27}$ Мельгунов С. Гражданская война в освещении П. Н. Милюкова... С. 16.

28 Зайцов А. 1918: очерки истории Русской Гражданской войны. Москва, Кучково поле, 2006. С. $333-334$.
} 
Thus, summing up, we can note that most researchers consider the revolution as a violent change of order, as a result of class struggle, and not just a change of power within the old regime. The revolution is not a normal state of society, on the contrary, it is the destruction of society and the state. Revolution leads to violence of law and order produces arbitrariness and outrage. At the first stage revolution often creates positive changes in society, but the weakness of government produces the frustration of society. The revolution never reaches the stated goals, instead of freedom it leads to dictatorship. Having reached its peak (in our case it is Bolshevism), the revolution enters a phase of terror (the Red terror, in our case), which causes resistance, i.e. the counter-revolution and the desire for restoration within society. Counter-revolution is a movement to restore order and the rule of law in society.

Society returns to the normal either by the victory of the counter-revolution or by the end of the revolution according to the principle of the "pendulum".

One of the most important manifestations of resistance to the spread of Bolshevism in the new states of Central and Eastern Europe was the Monarchist counter-revolution, which proved to be the most successful in Finland and Hungary.

The main factor of the emergence of the monarchist counter-revolution was the presence of a charismatic leader (in the meaning of Max Weber's terminology) who professed monarchical views. Other factors were the monarchist traditions in society and the intervention of neighboring monarchies.

Thus, it should be noted that, in cases of Russia (1917-1920), Ukraine (1917-1918), Finland (1918) and Hungary (1919), the most applicable theory of revolutionary process is still Pitirim Sorokin's "Sociology of Revolution", which identify three following stage of the revolutioncounter-revolution process:

1) The downfall of the monarchy, and the formation of the new government (in the former Russian Empire in March 1917 and in the Austro-Hungary in October 1918);

2) The Bolshevik coup, the proclamation of Soviet power, and the Red Terror (Russia 7 November 1917, Finland - 27 January 1918, Hungary - 21 March 1919);

3) The emergence of the counter-revolution forces, the White resistance, the victory of the counter-revolution over the Reds and the Restoration (Finland: 9 August 1918 - 17 July 1919, Ukraine: 29 April - 17 December 1918, Don: 18 May 1918 - 15 February 1919, and Hungary: 7 August 1919 - 16 October 1944) or the return to normal state in spite of the conservation of Soviet power (the NEP in Russia since 1921).

\section{REFERENCES}

1. Berend, I. (2003). History Derailed: Central and Eastern Europe in the Long Nineteenth Century. Oakland : University of California Press.

2. Calvert, P. (1970). A Study of Revolution. Oxford : Clarendon Press.

3. Catterall, P. (1997). What (if anything) is Distinctive about Contemporary History? Journal of Contemporary History, Vol. 32, 4, 441-452.

4. Fedyshyn, O. (2007). Ukrainskaya revolyuciya 1917-1918. Moskva : Centrpoligraf. [in Russian].

5. Goldstone, J. (Ed.) (2002). Revolutions: Theoretical, Comparative, and Historical Studies. Belmont : Thomson Wadsworth.

6. Goldstone, J. (1980). Theories of Revolution: The Third Generation., World Politics, (Vol. 32, № 3, 425-453).

7. Gurr, R. (1970). Why Men Rebel. Princeton, 1970.

8. Hobsbawm, E. (1975). The Age of Capital, 1848-1875. London : Weidenfeld \& Nicolson Ltd.

9. Hobsbawm, E. (1987). The Age of Empire, 1875-1914. London : Weidenfeld \& Nicolson Ltd.

10. Hobsbawm, E. (1962). The Age of Revolution: Europe, 1789-1848. London : Weidenfeld \& Nicolson Ltd.

11. Hroch, M. (1985). Social Preconditions of National Revival in Europe. A Comparative Analysis of the Social Composition of Patriotic Groups among the Smaller European Nations. Cambridge, London, New York, New Rochelle, Melbourne, Sydney : Cambridge University Press.

12. Huntington, S. (1968). Political Order in Changing Societies. New Haven : Yale University Press.

13. Jaszi, O. (1969). Revolution and Counter-Revolution in Hungary. New York : Howard Fertig.

14. Johnson, Ch. (1968). Revolutionary Change. London. 
15. Kenez, P. (1971). Civil War in South Russia, 1918. The First Year of the Volunteer Army. Berkeley, \& Los Angeles : University of California Press.

16. Lange, M. (2013). The Comparative Historical Methods. London, New Deli, Washington, Los-Angeles, Singapore : SAGE Pub.

17. Lindholm, C. (2013). The First and the Fourth Generation of Revolutionary Theories: A Common Ground for a Clinical Theory. Department of Political Science. Abo Akademi University Occasional Papers Series, 31, 1-40.

18. Mannerheim, K., G. (1999). Memuary. Moskva : Vagrius. [in Russian].

19. Mayer, A. (1971). Dynamics of Counter-revolution in Europe, 1870-1956. An Analytic Framework. New York \& Evanston \& San Francisco \& London : Harper Torchbooks.

20. Melgunov, S. (1929). Grazhdanskaya vojna v osveschenii P. N. Milyukova. (Po povodu "Rossiya na perelome”). Kritiko-bibliograficheskij ochrek. [Civil War in Milyukov's view. (On “Russia at a Turning Point”). The CritiqueBibliographical Essay]. Paris. [in Russian].

21. Milyukov, P. (1927). Rossiya na perelome: bolshevistskij period Russoj revolyucii. (Vol. I, II). Paris. [in Russian].

22. Palmowski, J., Spohr Readman, K. (2011). Speaking Truth to Power: Contemporary History in the Twenty-First Century. Journal of Contemporary History, Vol. 46, 3, 485-505.

23. Pipes, R. (1997). Rossiya pri bolshevikakh. Moskva : ROSSPEN. [in Russian]

24. Salert, B. (1981). Revolutions and Revolutionaries: Four Theories. Santa Barbara : Praeger Publishers.

25. Skockpol, Th. (1979). States and Social Revolution. Cambridge.

26. Smolin, O. (2004). Politicheskij process v sovremennoj Rossii. Moskva : Velbi \& Prospect [in Russian].

27. Sorokin, P. (1992). Revolyuciya i sociologiya. Bojnya : revolyuciya 1917 goda. Moskva.[in Russian].

28. Sorokin P. Chelovek. Civilizaciya. Obshhestvo. Moskva.[in Russian].

29. Sorokin, P. (2005). Sociologiya revolyucii. Moskva : ROSSPE'N. [in Russian].

30. Spohr Readman, K. (2011). Contemporary History in Europe: From Mastering National Past to the Future of Writing the World. Journal of Contemporary History. Vol. 46, № 3, 506-530.

31. Stern, F. (ed.). (1970). The Varieties of History from Voltaire to the Present. London \& Basingstoke : MacMillan Ltd., 457 p.

32. Sztompka, P. (1996). Sociologia social'nykh izmenenij [Sociology of Social Changes]. Moskva [Moscow]. 416 p. [in Russian].

33. Taylor, S. (1984). Social Science and Revolutions. London, 176 p.

34. Tilly, Ch. (1963). The Analysis of A Counter-Revolution. History and Theory, Vol. 3, No. 1, p. 30-58.

35. Tilly, Ch. (1996). European Revolutions, 1492-1992. Oxford : Blackwell Publishers Ltd.

36. Tilly, Ch. (1978). From Mobilization to Revolution. New York : Random House.

37. de Tocqueville, A. (1997). Staryj poryadok i revolyuciya. Moskva. [in Russian].

38. Tosh, J. (2002). The Pursuit of History: Aims, Methods and New Directions in the Study of Modern History. London : Longman.

39. Zajcov, A. (2006). 1918: Ocherki istorii Russkoj Grazhdanskoj vojny. Moskva : Kuchkovo pole. [in Russian].

Дмитро БОНДАРЕНКО, докторант,

Університет Сегеда,

Сегед, Угоричина

e-mail:dbond70@gmail.com

ORCID ID: https://orcid.org/0000-0003-1608-1282,

ResearcherID: X-9811-2019,

https://publons.com/researcher/3108443/dmytro-bondarenko/

\section{ПРОЦЕС РЕВОЛЮЦӤ-КОНТРРЕВОЛЮЦІЇ В ЦЕНТРАЛЬНІЙ ТА СХІДНІЙ СВРОПІ 1917-1920 РОКІВ: ТЕОРЕТИЧНИЙ ОГЛЯД}

У статті проведено короткий аналіз процесів революиї $і$ контрреволюиї в деяких державах Центральної та Східної Свропи в 1917-1920рр. на підставі найбільш значущих історико-сочіологічних досліджень Питирима Сорокіна, Оскара Яси, Чарльза Тіллі, Пйотра Штомпки та ін. Виявлено основні фази $i$ закономірності револючійних процесів. Продемонстровано, щчо прочес револючії $і$ контрреволюиії в різних країнах Центральної та Східної Свропи мав однакові причини, фази розвитку $і$ закономірності, але призвів до різних результатів. Наприклад, кульмінацією револющії в усіх розглянутих країн був більшовизм та Червоний терор, і контрреволючія виникала саме як відповідь на иі явища. Тобто, револючія починалась із ліберальнодемократичної фази, потім переходила до другої фази - більшовицької диктатури. Саме тут виникла контрреволюиія як відповідь на виклик більшовизму, яка також мала деякі етапи та особливості. Наприклад, якщо у Фінляндї контрреволюція перемогла самостійно, то в Украӥні та Угорщині - через інтервенщію сусідніх держав, а в Росії вона взагалі не перемогла. Тут треба зауважити, щьо Гетьманський переворот в Україні та проголошення Украӥнської Держави було проявом саме контрреволючї, а не так званого 
«консервативного етапу украӥнської революиії», як иче вважається в сучасній українській історіографії. Таким чином, історія продемонструвала деякі закономірності револючійного прочесу, який мав подібні причини $i$ фази, але різні результати і наслідки. Наприклад, якщо у Фінляндії та Угорщині більшовизм зазнав поразки та перемогла контрреволючія, то в Росії, навпаки, більшовикам вдалося зберегти владу, проте, вони вимушені були зробити значні поступки суспільству у вигляді НЕП. Ця проблема досліджена в цій статті, застосовуючи порівняльно-історичний аналіз.

Ключові слова: револючія; контрреволючія; монархічна контрреволючія; реставрація; Центральна та Східна Європа в 1918-1920 роках; більшовизм; Питирим Сорокін; Чарльз Тіллі; Оскар Яси.

The author wishes to thank for advice professors of the University of Szeged Béla Tomka and Peter Bencsik. Автор висловюс подяку за поради професорам Сегедського університету Бела Томка та Петеру Бенчику.

Рецензенти: Морозова О., канд. іст. наук, доцент; Левченко Л., д-р іст. наук, професор.

(C) Bondarenko D., 2019

Статтю подано до редакції 16.09.2019 